Article

\title{
Structure of the PLP-Form of the Human Kynurenine Aminotransferase II in a Novel Spacegroup at $1.83 \AA$ A Resolution
}

\author{
Alireza Nematollahi ${ }^{1}$, Guanchen Sun ${ }^{1}$, Stephen J. Harrop ${ }^{2}$, Jane R. Hanrahan ${ }^{3}$ and \\ W. Bret Church ${ }^{1, *}$ \\ 1 Group in Biomolecular Structure and Informatics, Faculty of Pharmacy, University of Sydney, Sydney, \\ NSW 2006, Australia; anem7250@uni.sydney.edu.au (A.N.); gsun2866@uni.sydney.edu.au (G.S.) \\ 2 MX Beamlines, Australian Synchrotron, 800 Blackburn Road, Clayton, VIC 3168, Australia; \\ stephen.harrop@synchrotron.org.au \\ 3 Faculty of Pharmacy, University of Sydney, Sydney, NSW 2006, Australia; jane.hanrahan@sydney.edu.au \\ * Correspondence: bret.church@sydney.edu.au; Tel.: +61-2-9356-6569; Fax: +61-2-9351-4391
}

Academic Editor: Charles A. Collyer

Received: 12 February 2016; Accepted: 22 March 2016; Published: 25 March 2016

\begin{abstract}
Kynurenine aminotransferase II (KAT-II) is a $47 \mathrm{kDa}$ pyridoxal phosphate (PLP)-dependent enzyme, active as a homodimer, which catalyses the transamination of the amino acids kynurenine (KYN) and 3-hydroxykynurenine (3-HK) in the tryptophan pathway, and is responsible for producing metabolites that lead to kynurenic acid (KYNA), which is implicated in several neurological diseases such as schizophrenia. In order to fully describe the role of KAT-II in the pathobiology of schizophrenia and other brain disorders, the crystal structure of full-length PLP-form hKAT-II was determined at $1.83 \AA$ resolution, the highest available. The electron density of the active site reveals an aldimine linkage between PLP and Lys263, as well as the active site residues, which characterize the fold-type I PLP-dependent enzymes.
\end{abstract}

Keywords: kynurenine aminotransferase; crystal structure; neurodegenerative diseases; pyridoxal phosphate (PLP)

\section{Introduction}

Kynurenic acid (KYNA), with several specific biological activities, is known to antagonize all ionotropic glutamate receptors. The antagonisation of the $N$-methyl-D-aspartate (NMDA) receptor occurs by binding at the glycine binding site [1] and at the $\alpha$-amino-3-hydroxy-5-methyl4-isoxazolepropionic acid receptor (AMPA) as well as at the lesser studied Kainate receptor, and at each of which then causes neuronal excitation [2,3], and accelerates the neuronal death rate [4]. Therefore the physiological role described for KYNA which prevents glutamate receptors from becoming excessively excited establishes it as crucial for brain stability under normal physiological conditions [5]. In addition, it is clear that increased KYNA levels protects neurons against ischemic brain damage, and also anti-seizure activity is known [6,7]. More recently, studies revealed that $\alpha 7$-nicotinic acetylcholine receptors ( $\alpha 7$-nAChRs) are inhibited by KYNA, and this results in a decreased release of glutamate, which balances levels of extracellular dopamine [8]. Furthermore, among other literature reports effects on the G protein-coupled receptor 35 (GPR35) are attributed to KYNA, a receptor which is mainly expressed in immune cells [9], suggesting KYNA might play a more general role in immunological regulation. As inflammation (resulting from viral and bacterial infections) can activate the tryptophan catabolic pathway $[10,11]$, the ensuing tryptophan catabolism decreases plasma levels of tryptophan and increases KYNA plasma levels [12,13]. KYNA also exhibits antioxidant activity due to its 
capability of scavenging free radical agents $[14,15]$ which is independent of its pharmacological actions at receptors.

Regardless of the evidence for the participation of KYNA in neuroprotection, the potential for cognitive damage in the central nervous system (CNS) which results from the involvement of glutamatergic and cholinergic neurotransmission needs appropriate consideration [16], especially in the context of the negative symptoms of schizophrenia. Studies on the cerebrospinal fluid (CFS) of patients affected by schizophrenia revealed that KYNA levels were raised [17,18]. Consequently, KYNA can potentially have both the neuroprotective and the cognitive impairing effects. As a result of the latter observations several neurodegenerative diseases are linked with the kynurenine metabolic pathway and brain KYNA levels. In addition to cognitive impairment brain KYNA levels have been shown to play a key role in other CNS diseases such as Huntington's disease [19], Alzheimer's disease and schizophrenia [20].

It is believed that in the CNS of mammals kynurenine aminotransferase (KAT) isozymes are responsible for the synthesis of KYNA [21]. Both KAT I and KAT II are seen to be substantially expressed in astrocytes [22], and are actively involved in the human brain which has the requirement for KYNA [23,24]. Our focus here is on KAT-II, which is a biologically active homodimer, and reportedly produces almost $75 \%$ of KYNA in human brain [25]. More recently several researchers have downplayed the importance of KAT I and KAT III in the brain [26]. The KATs irreversibly convert L-kynurenine (L-KYN), the main intermediate of the kynurenine pathway into KYNA, an endogenous neuroactive agent in CNS [25], as part of the main route of the tryptophan degradation pathway [27].

KAT-II consists of 425 amino acid residues with its catalytic site at the homodimeric interface. It belongs to the subgroup $\mathrm{I}_{\beta}$ and $1_{\gamma}$ of the pyridoxal-5'-phosphate (PLP) dependent aminotransferases $[28,29]$ with its optimum activity at $\mathrm{pH} 7.0-7.5$. PLP acts as a coenzyme and is covalently linked to Lys263 by a "Schiff base" reaction, resulting in an aldimine linkage. As the initial step of the enzymatic reaction pathway, the substrate L-KYN binds at the active site of the kynurenine aminotransferase and consequently the aldimine bond is broken, and the PLP then binds to the $\alpha$-amino group of the L-KYN. In the ensuing steps this $\alpha$-amino group is transferred to the coenzyme, converting the PLP to the pyridoxamine phosphate (PMP) form. Regeneration of PLP is achieved by the transfer of the $\alpha$-amino group to the $\alpha$-keto acid, leaving the $\alpha$-keto acid co-substrate with L-KYN, which spontaneously undergoes a ring closure producing KYNA [30]. In this paper we describe the three-dimensional (3D) crystal structure of the PLP form of hKAT-II (PDB entry: 5EUN) in the novel space group $P 4_{3} 2{ }_{1} 2$, at $1.83 \AA$ resolution, which is the highest available for the hKAT-II structure. The high resolution facilitates further study of the active site role including nearby residues and their possible involvement in the catalysis mechanism. Our structure is also valuable for the rational design of inhibitors for the purposes of their consideration as therapeutics for numerous CNS diseases in humans.

\section{Results and Discussion}

\subsection{Purification and Activity Assay of hKAT-II}

Using the Ni-NTA column chromatography method, the recombinantly expressed hKAT-II enzyme was purified, and its activity with the substrate $(K Y N)$ and co-substrate ( $\alpha$-ketoglutarate) was determined using HPLC (Figure 1). The activity assay results were consistent with previous reports of recombinant hKAT-II activity with $\alpha$-ketoglutarate as co-substrate (Figure 1) [31,32]. 


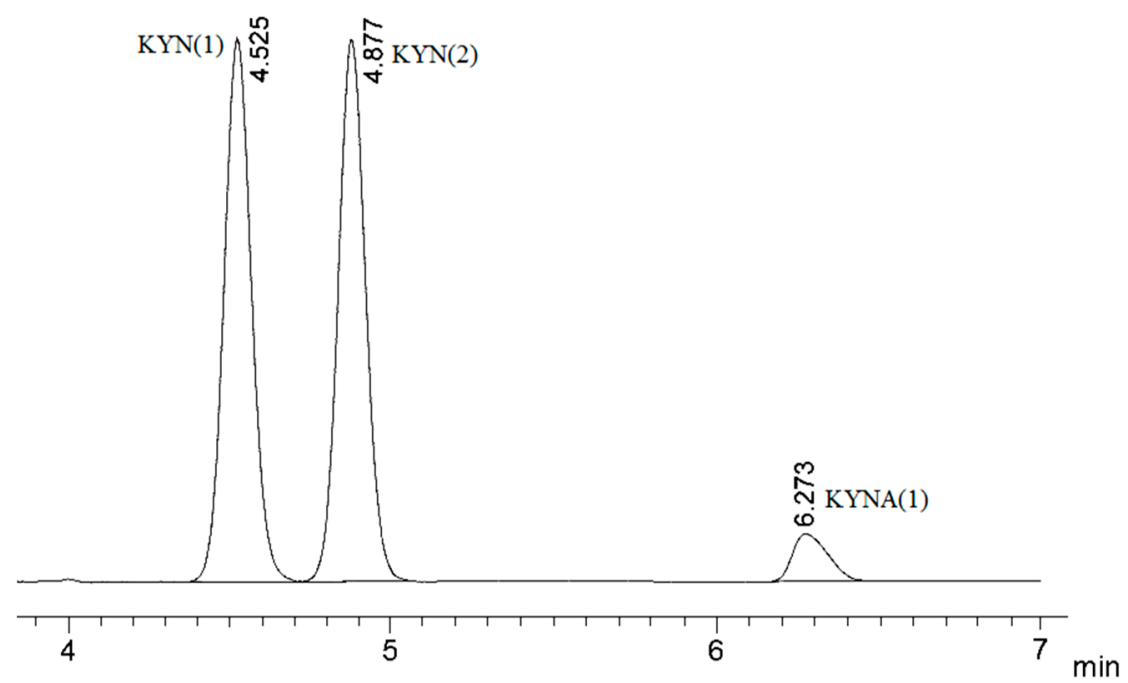

Figure 1. HPLC-based activity assay in which the mobile phase used was a water-acetonitrile (93:7) mixture and the detection wavelength was $330 \mathrm{~nm}$. Injection (1) hKAT-II incubated with kynurenine (KYN), pyridoxal phosphate (PLP) and $\alpha$-ketoglutarate in which kynurenic acid (KYNA) peak was observed; Injection (2) indicates the control that was missing hKAT-II in otherwise the same reaction mixture only has detected the KYN peak.

\subsection{Overall Structure}

The crystal of our hKAT-II holoenzyme, with the PLP form of the co-factor, diffracted to $1.83 \AA$. The crystals belonged to the novel tetragonal space group $P 4_{3} 2_{1} 2$ with unit cell dimensions of $a=102.46 \AA, b=102.46 \AA$ and $c=86.24 \AA\left(\alpha, \beta\right.$ and $\left.\gamma=90^{\circ}\right)$. The asymmetric unit contains one molecule with an estimated solvent content of $48.1 \%$. The molecular replacement (MR) solution had a $\log$ likelihood gain (LLG) of 12999 and a translation function Z-score of 107. The final fully refined structure was achieved with a final $R$-free and $R$-work of $19.89 \%$ and $17.30 \%$, respectively, in which the agreement between them indicates over-fitting is unlikely. The final model contains all the residues of a total of 425 , containing the one modified residue, LLP (lysine-pyridoxal-5' - phosphate (LLP), which is substituted for Lys263), and 438 solvent molecules. The geometry and stereochemistry of the structure were assessed by MolProbity [33] and $95.5 \%$ of residues are within the most favored regions and other $4.5 \%$ are within the allowed regions of the Ramachandran plot. Two cis peptide conformations were determined, at Pro140 and 203. The hKAT-II structure contains 37\% $\alpha$-helix, $15 \% \beta$-sheet, $12 \%$ turn, $35 \%$ coil and $1 \% 3_{10}$ helix. Unambiguous electron density was generally observed, and the $\mathrm{N}$-terminal arm consisting of an antiparallel $\beta$-sheet ( $\beta 1-\beta 2$ strands; between Ala51 and Gly64) (Figure 2a). The state in which the side chain amino group of Lys 263 forms an aldimine bond with PLP, also referred to as the resting state is the state of the hKAT-II observed with no ambiguity in the electron density maps. (Figure 2b). Also the N-terminal arm is observed rolled into the location away from the active site, which does not otherwise affect the active site pocket. The large domain of the protein consists of seven $\beta$ strands ( $\beta 3-\beta 9)$ and the small domain (also known as the C-terminal arm) consists of three $\beta$-sheets ( $\beta 10-\beta 12)$ (Figure 3). From previous studies $[34,35]$ of the PLP-dependent enzymes of fold type I the binding cup is seen to include hydrogen bonds and salt bridges, which involves the phosphate group of LLP as anticipated (shown in Figure 4a). The oxygen of the pyridine ring hydroxyl moiety of LLP interacts with Asn202 and Tyr233, and the pyridine ring is also sitting parallel to and alongside the Tyr142 ring. Additionally, the pyridoxal ring of LLP has a hydrophobic interaction with Pro232, not previously reported in the other available aminotransferase structures [4]. The side chain carboxylate oxygen of Asp230 takes part in a hydrogen bond with the NH pyridinium of LLP, which is seen to exist across all fold-type I proteins of the PLP-dependent enzyme family, which is generally considered crucial for enzyme function [36-38] (Figure 4b). Our hKAT-II structure crystal has 
minimal crystallographic complexity as there is only one molecule in the asymmetric unit, compared to other available structures which have been reported with up to 4 crystallographically independent molecules (i.e., PDB entry 2R2N, at $1.95 \AA$ resolution). The PLP ligand linked through the aldimine bond to Lys263, required for activity in the PLP-dependent enzyme families, is not always observed as examples exist in the apo form without the PLP, as in the case of the structures reported by Ku et al., 2006 [39] (PDB entry 2C44) and Hasse et al., 2013 [40] (PDB entry 4LGL). The biological dimer is observed faithfully in the crystal structure. To assess the experimental precision in the determination of the atomic positions in a protein crystal structure, the diffraction precision index (DPI) is the metric to which one defers [41]. DPI for all ligand free hKAT-II entries were calculated based on the formula using several variables pertinent to the precision calculations and summarized in Table 1, showing the superior precision of atomic positions determined in our structural studies.
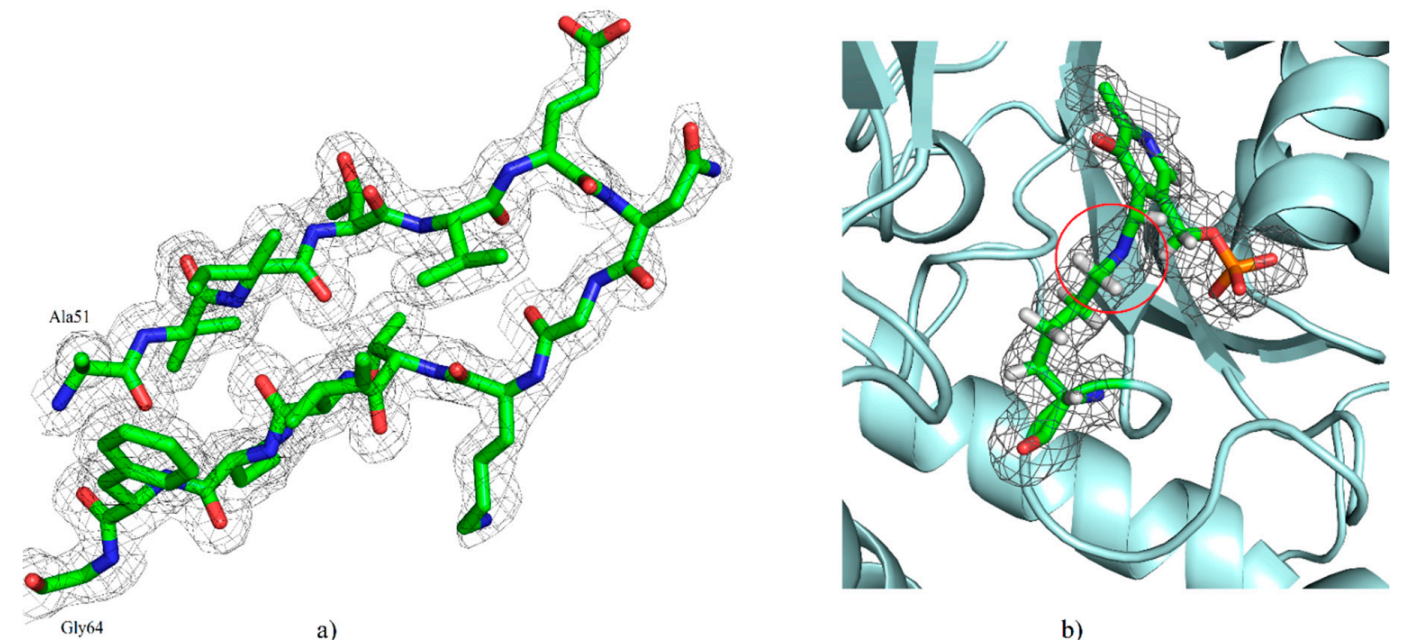

b)

Figure 2. (a) Illustrative electron-density depiction from the final 2Fo-Fc map (grey at the $1.0 \sigma$ level), highlighting the agreement of antiparallel $\beta$-sheets ( $\beta 1-\beta 2$; between Ala51 and Gly64) with the maps; (b) The 2Fo-Fc electron density map (grey at the $0.5 \sigma$ level) of lysine-pyridoxal-5' -phosphate (LLP)263, in which the aldimine linkage is highlighted by a red circle.

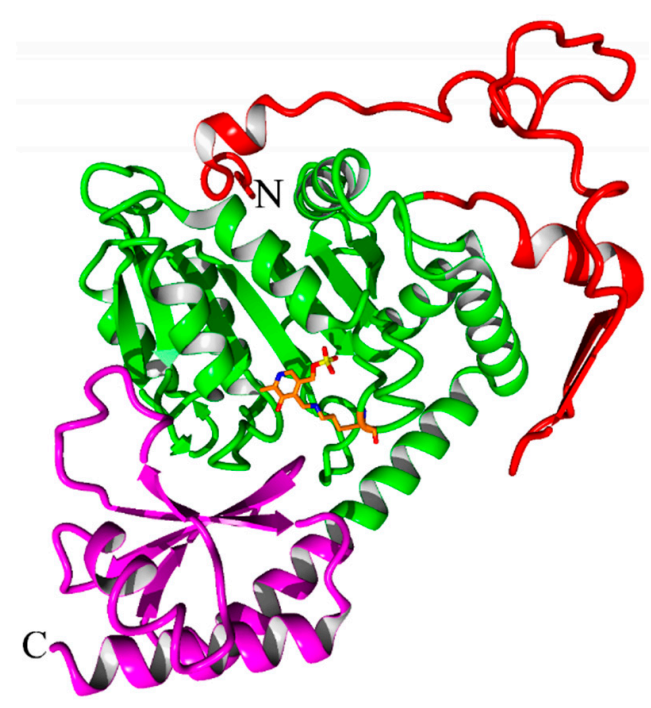

Figure 3. The structure of hKAT-II. The secondary structure elements are shown with the cofactor, PLP. The N-terminal arm is depicted in red, the large domain in green, the C-terminal arm is in magenta and the LLP263 is shown in orange stick representation. The termini are labelled with $\mathrm{N}$ and C. 

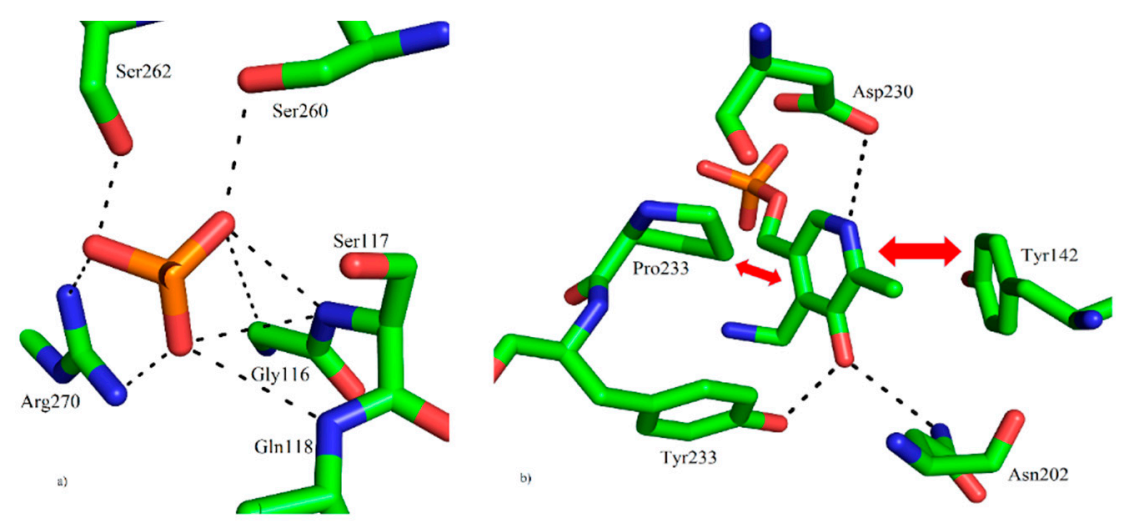

Figure 4. (a) The binding cup interactions of the phosphate group of LLP in the resting state of hKAT-II. The phosphate of LLP forms polar interactions with the residues Gly116, Ser117, Gln118, Ser262 and Arg-270; (b) Hydrophilic (hydrogen bond) interactions of Tyr233 and Asn202 with the pyridoxal ring of LLP, as well as polar interactions of Asp230 with pyridine nitrogen of LLP, which is a characteristic of the fold type-I of the PLP-dependent enzyme family. The hydrophobic interactions are with the sidechains of Tyr142 and Pro233, highlighted by red arrows. Hydrogen bonds are all represented with black broken lines.

Table 1. The diffraction precision index (DPI) of hKAT-II PDB entries.

\begin{tabular}{cc}
\hline PDB Entry Code & DPI * (̊) \\
\hline 5EUN (structure reported here) & 0.12 \\
2R2N & 0.20 \\
2QLR & 0.50 \\
2VGZ & 0.31 \\
3DC1 & 0.32 \\
\hline ated DPI $(\AA)$ using $R_{\text {work }}$ using Webserver Program [42].
\end{tabular}

\section{Materials and Methods}

\subsection{Enzyme Expression and Purification}

Using the online Genscript tool followed by manual intervention the hKAT-II gene was optimized for heterologous expression in E. coli and the nucleotide sequence was constructed by Genscript Corporation, Piscatway, NJ, USA. The optimized sequence was sub-cloned into a pET15b vector via $\mathrm{NdeI} / \mathrm{BamHI}$ restriction sites. The expression vector was transformed into Rosetta 2 competent cells, the protein expression induced by adding $0.1 \mathrm{mM}$ isopropyl $\beta$-D-1-thiogalactopyranoside (IPTG) for $24 \mathrm{~h}$ at $15{ }^{\circ} \mathrm{C}$, and later bacterial pellets were harvested by centrifugation and stored at $-80^{\circ} \mathrm{C}$. The pET15b vector added a hexa-histidine $(6 \times$ His $)$ tag to the $\mathrm{N}$-terminus of the expressed protein which allowed it to be purified using nickel-nitrilotriacetic acid (Ni-NTA) column chromatography. The purified recombinant hKAT-II was concentrated to $16 \mathrm{mg} / \mathrm{mL}$ using an Amicon ${ }^{\circledR}$ ultra $4 \mathrm{~mL}$ centrifugal filter unit with a membrane size of $30 \mathrm{kDa}$. The enzyme purity was evaluated by SDS-PAGE analysis [32]. Enzyme production is summarized in Table 2.

Table 2. Enzyme production.

\begin{tabular}{cc}
\hline Source Organism & Homo Sapiens \\
\hline DNA source & Synthesized (GenScript, Piscataway, NJ, USA) \\
$5^{\prime}$ sequence & BamHI/NdeI site: GGATCCCATATG \\
$3^{\prime}$ sequence & Stop codon and BamHI site: TAATAAGGATCC \\
Cloning vector & pUC57 \\
Expression vector & pET15b \\
Expression host & E. coli Rosetta 2 \\
\hline
\end{tabular}




\subsection{Activity Assay}

The activity assay was designed based on the previously described method with slight modifications [4]. A $50 \mu \mathrm{L}$ reaction mixture containing $5 \mathrm{mM}$ of L-kynurenine, $5 \mathrm{mM}$ of $\alpha$-ketoglutarate, $40 \mu \mathrm{M}$ PLP and $0.9 \mu \mathrm{g}$ purified hKAT2 in $10 \mathrm{mM}$ phosphate buffer ( $\mathrm{pH} 7.5$ ) was used to determine the activity of the recombinant protein. The reaction mixture was incubated at $37^{\circ} \mathrm{C}$ for $10 \mathrm{~min}$ and then an equal volume of $0.8 \mathrm{M}$ formic acid was added to terminate the reaction. After centrifuging at $11,000 \times g$ at $4{ }^{\circ} \mathrm{C}$ for $10 \mathrm{~min}$ the supernatant was stored for the HPLC assay. KYN and KYNA peaks were detected at $330 \mathrm{~nm}$ using a C-18 reverse-phase column with water-acetonitrile (93:7) $v / v \%$ as the mobile phase.

\subsection{Crystallization, Data Collection, Structure Solution and Refinement}

Crystals of the recombinant human kynurenine aminotransferase II were grown using the vapor diffusion method with hanging drops technique. Protein $(1 \mu \mathrm{L})$ at a concentration of $7 \mathrm{mg} / \mathrm{mL}$ was mixed with an equal volume of a reservoir solution containing $200 \mathrm{mM} \mathrm{NaCl}, 0.1 \mathrm{M} \mathrm{NaCitrate} \mathrm{pH} 5.6$, $24 \%$ PEG4K and equilibrated against $1 \mathrm{~mL}$ of a reservoir solution at $20^{\circ} \mathrm{C}$ (as described in Table 3). Tetragonal bipyramidal crystals grew to a maximum dimension of $0.3 \times 0.4 \times 0.8 \mathrm{~mm}$ in one week.

Table 3. Crystallization.

\begin{tabular}{cc}
\hline Crystallization Method & Hanging Drop Vapor Diffusion \\
\hline Plate type & 24-well Tissue plate \\
Temperature $(\mathrm{K})$ & 293.15 \\
Protein concentration $(\mathrm{mg} / \mathrm{mL})$ & 7 \\
Buffer of protein solution & $20 \mathrm{mM}$ Tris- $\mathrm{HCl}, \mathrm{pH} 8.0,50 \mathrm{mM} \mathrm{NaCl}$ \\
Reservoir solution & $200 \mathrm{mM} \mathrm{NaCl}, 0.1 \mathrm{M}, \mathrm{NaCitrate} \mathrm{pH} 5.6,24 \%$ PEG4K \\
Volume and ratio of drop & $2 \mu \mathrm{L}, 1: 1$ ratio \\
Volume of reservoir $(\mathrm{mL})$ & 1 \\
\hline
\end{tabular}

Diffraction data were collected at the Australian Synchrotron Beamline MX2 (Clayton, Australia) at $100 \mathrm{~K}$ using the Blue-Ice software package [43]. Data processing was done using the XDS program with Aimless scaling and merging [44,45]. The structure of recombinant human kynurenine aminotransferase II was determined by molecular replacement (MR) using PHASER [46] with an ensemble structure generated by using the SCULPTOR [47] and ENSEMBLER features implemented in PHENIX (Ver 1.10.1-2155) [48] from the PDB entries (2R2N, 2QLR, 2VGZ and 3DC1) [4,49-53] and homology model built by YASARA [54]. The built model was refined by Phenix.refine [55], and to improve the quality of the protein model and perform corrections, modifications of the side-chain $x$ dihedral angles were performed with the side-chain rotator tool in KiNG (Kinemage) version 2.21 [56] with the most recent version of the "Penultimate Rotamer Library" [57]. Additionally the Backrub tool [58] implemented in KiNG (Kinemage) was used to adjust the protein backbone to apply fixes in the cases which were not improved by side chain movement alone. The rebuilding process was accomplished using the amended model and then the coordinates, individual temperaturefactors and occupancies were refined and the weight of geometry was optimized against the data. The final structure was refined at $1.83 \AA$ resolution and the quality of the structure was evaluated by PHENIX comprehensive validation tools $[33,59]$. Data collection, processing and structure refinement statistics are summarized in Table 4. Structure figures were created using PyMOL [60] and YASARA [54]. Coordinates and structure factors have been deposited at the Protein Data Bank (PDB) server with PDB entry 5EUN. 
Table 4. Data collection and refinement statistics.

\begin{tabular}{|c|c|}
\hline Diffraction Source & Australian Synchrotron MX2 \\
\hline Wavelength $(\AA)$ & 0.9537 \\
\hline Temperature (K) & 100 \\
\hline Detector & ADSC QUANTUM 315r CCD \\
\hline Crystal-to-detector distance (mm) & 250 \\
\hline Rotation range per image $\left(^{\circ}\right)$ & 1.0 \\
\hline Total rotation range $\left({ }^{\circ}\right)$ & 180 \\
\hline Exposure time per image (s) & 1 \\
\hline Space group & $P 4_{3} 2_{1} 2$ \\
\hline Unit cell $\left(\AA \stackrel{\circ}{\circ}^{\circ}\right)$ & $a=b=102.46, c=86.24(\alpha, \beta$ and $\gamma=90)$ \\
\hline Resolution $(\AA)$ & $39.74-1.825(1.891-1.825) *$ \\
\hline Total reflections & $81,444(6884)$ \\
\hline Unique reflections & $40,739(3147)$ \\
\hline Multiplicity & $2.0(2.0)$ \\
\hline Completeness (\%) & $98.5(85.1)$ \\
\hline$\langle I / \sigma(I)\rangle$ & $17.64(2.87)$ \\
\hline Wilson $B$-factor & 17.44 \\
\hline$R_{\text {merge }}$ & $0.0231(0.1859)$ \\
\hline$R_{\text {meas }}$ & $0.03267(0.2629)$ \\
\hline $\mathrm{CC}_{1 / 2}$ & $0.999(0.909)$ \\
\hline Reflections used in refinement & $39644(3147)$ \\
\hline Reflections used for $R_{\text {free }}$ & $1942(152)$ \\
\hline$R_{\text {work }}$ & $0.1730(0.2148)$ \\
\hline$R_{\text {free }}$ & $0.1988(0.2696)$ \\
\hline $\mathrm{CC}_{\text {work }}$ & $0.958(0.906)$ \\
\hline $\mathrm{CC}_{\text {free }}$ & $0.932(0.780)$ \\
\hline Protein residues & 425 \\
\hline R.m.s. (bonds) & 0.004 \\
\hline R.m.s (angles) & 0.72 \\
\hline Average $B$-factor & 27.95 \\
\hline Ramachandran favored (\%) & 95.5 \\
\hline Ramachandran allowed (\%) & 4.5 \\
\hline Ramachandran outliers (\%) & 0 \\
\hline Rotamer outliers (\%) & 0.81 \\
\hline Clashscore & 2.69 \\
\hline PDB ID & $5 E U N$ \\
\hline
\end{tabular}

* Statistics for the highest-resolution shell are shown in parentheses.

\subsection{Homology Modeling}

In order to obtain the high-accuracy ensemble structure as a reference model for molecular replacement, the homology modeling technique was used. The homology model of hKAT-II was constructed using YASARA [54]. The primary sequence of hKAT-II was obtained from the Swiss-Prot database (Q8N5Z0) [61] which has a total of 425 residues in the monomer. Using PSI-BLAST 209 hits were found, and 25 models were built using the highest score templates. Specifically, first an alignment of target and template residues was calculated for each of the templates, and the sequence identity and the sequence similarity determined. The alignment considers structural information, as well as the predicted target secondary structure [62]. The loops were then modelled and optimized by conformation sampling and optimization of all the sidechains with a medium computational demand. Optimization occurred using electrostatic and knowledge-based packing interactions, with consideration of solvation effects as implemented in the YASARA2 force field, achieving fine tuning of the model. Finally, YASARA provides a hybrid model by combining the best parts of the 25 constructed models, in an attempt to increase the accuracy beyond each of the contributory individual models. The hybrid model with a z-score of -0.101 was selected as the best model, and it was of satisfactory quality to provide success in the molecular replacement procedure. 


\section{Conclusions}

Human kynurenine aminotransferase II makes the largest contribution to KYNA production in human brains and plays a key role in several CNS disorders. Therefore, it is a biological target of interest that may be important in considerations of how to overcome neurodegenerative diseases. In this paper the native structure of hKAT-II (PLP form) at $1.83 \AA$ has been determined and refined, providing the highest resolution structure reported. This resultant model gives a complete, detailed description of the binding site of hKAT II, which is of considerable practical use, especially in the context of the challenge to design novel therapeutic lead inhibitors targeting this enzyme.

Acknowledgments: Authors would like to acknowledge the support of the Australian Synchrotron MX2 for the use of their X-ray facility. This work was supported by The Rebecca L. Cooper Medical Research Foundation (WBC). The authors also wish to thank members of their respective research groups for a supportive environment and their collegiality.

Author Contributions: Alireza Nematollahi and Guanchen Sun conducted the protein production; Alireza Nematollahi, Guanchen Sun and Stephen J. Harrop the diffraction data collection; Alireza Nematollahi and W. Bret Church solved and analyzed the data and structure; Jane R. Hanrahan contributed chemistry expertise; W. Bret Church, Alireza Nematollahi and Guanchen Sun designed the experiments; Alireza Nematollahi and W. Bret Church wrote and with Jane R. Hanrahan revised the paper. All authors read and agreed with the final manuscript.

Conflicts of Interest: The authors declare no conflict of interest.

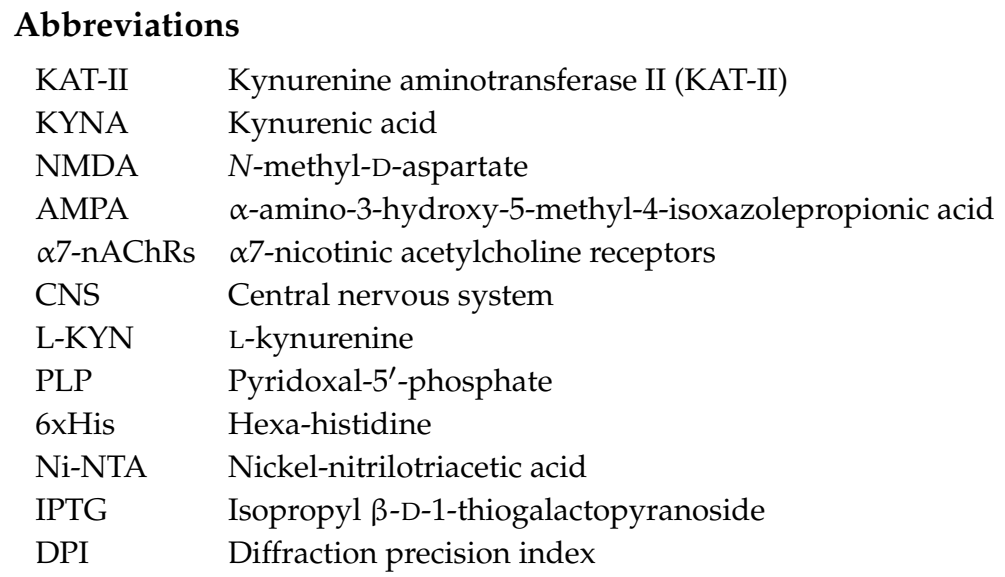

\section{References}

1. Battaglia, G.; Rassoulpour, A.; Wu, H.Q.; Hodgkins, P.S.; Kiss, C.; Nicoletti, F.; Schwarcz, R. Some metabotropic glutamate receptor ligands reduce kynurenate synthesis in rats by intracellular inhibition of kynurenine aminotransferase II. J. Neurochem. 2000, 75, 2051-2060. [CrossRef] [PubMed]

2. Palmada, M.; Centelles, J.J. Excitatory amino acid neurotransmission. Pathways for metabolism, storage and reuptake of glutamate in brain. Front. Biosci. 1998, 3, d701-d718. [PubMed]

3. Martin, S.J.; Grimwood, P.D.; Morris, R.G. Synaptic plasticity and memory: An evaluation of the hypothesis. Annu. Rev. Neurosci. 2000, 23, 649-711. [CrossRef] [PubMed]

4. Han, Q.; Robinson, H.; Li, J. Crystal structure of human kynurenine aminotransferase II. J. Biol. Chem. 2008, 283, 3567-3573. [CrossRef] [PubMed]

5. Chon, H.; Matsumura, H.; Koga, Y.; Takano, K.; Kanaya, S. Crystal structure of a human kynurenine aminotransferase II homologue from Pyrococcus horikoshii OT3 at $2.20 \AA$ A resolution. Proteins 2005, 61, 685-688. [CrossRef] [PubMed]

6. Andine, P.; Lehmann, A.; Ellren, K.; Wennberg, E.; Kjellmer, I.; Nielsen, T.; Hagberg, H. The excitatory amino acid antagonist kynurenic acid administered after hypoxic-ischemia in neonatal rats offers neuroprotection. Neurosci. Lett. 1988, 90, 208-212. [CrossRef]

7. Foster, A.C.; Vezzani, A.; French, E.D.; Schwarcz, R. Kynurenic acid blocks neurotoxicity and seizures induced in rats by the related brain metabolite quinolinic acid. Neurosci. Lett. 1984, 48, 273-278. [CrossRef] 
8. Vecsei, L.; Szalardy, L.; Fulop, F.; Toldi, J. Kynurenines in the CNS: Recent advances and new questions. Nat. Rev. Drug Discov. 2013, 12, 64-82. [CrossRef] [PubMed]

9. Wang, J.H.; Simonavicius, N.; Wu, X.S.; Swaminath, G.; Reagan, J.; Tian, H.; Ling, L. Kynurenic acid as a ligand for orphan G protein-coupled receptor GPR35. J. Biol. Chem. 2006, 281, 22021-22028. [CrossRef] [PubMed]

10. Mellor, A.L.; Munn, D.H. IDO expression by dendritic cells: Tolerance and tryptophan catabolism. Nat. Rev. Immunol. 2004, 4, 762-774. [CrossRef] [PubMed]

11. Schwarcz, R.; Bruno, J.P.; Muchowski, P.J.; Wu, H.Q. Kynurenines in the mammalian brain: When physiology meets pathology. Nat. Rev. Neurosci. 2012, 13, 465-477. [CrossRef] [PubMed]

12. Oxenkrug, G.F. Tryptophan-Kynurenine Metabolism as a common mediator of genetic and environmental impacts in major depressive disorder: The serotonin hypothesis revisited 40 years later. Isr. J. Psychiatry Relat. Sci. 2010, 47, 56-63. [PubMed]

13. Stone, T.W.; Darlington, L.G. Endogenous kynurenines as targets for drug discovery and development. Nat. Rev. Drug Discov. 2002, 1, 609-620. [CrossRef] [PubMed]

14. Lugo-Huitron, R.; Blanco-Ayala, T.; Ugalde-Muniz, P.; Carrillo-Mora, P.; Pedraza-Chaverri, J.; Silva-Adaya, D.; Maldonado, P.D.; Torres, I.; Pinzon, E.; Ortiz-Islas, E.; et al. On the antioxidant properties of kynurenic acid: Free radical scavenging activity and inhibition of oxidative stress. Neurotoxicol. Teratol. 2011, 33, 538-547. [CrossRef] [PubMed]

15. Hardeland, R.; Zsizsik, B.K.; Poeggeler, B.; Fuhrberg, B.; Holst, S.; Coto-Montes, A. Indole-3-pyruvic and -propionic acids, kynurenic acid, and related metabolites as luminophores and free-radical scavengers. Adv. Exp. Med. Biol. 1999, 467, 389-395. [PubMed]

16. Szalardy, L.; Zadori, D.; Toldi, J.; Fulop, F.; Klivenyi, P.; Vecsei, L. Manipulating kynurenic acid levels in the brain-On the edge between neuroprotection and cognitive dysfunction. Curr. Top. Med. Chem. 2012, 12, 1797-1806. [CrossRef] [PubMed]

17. Erhardt, S.; Blennow, K.; Nordin, C.; Skogh, E.; Lindstrom, L.H.; Engberg, G. Kynurenic acid levels are elevated in the cerebrospinal fluid of patients with schizophrenia. Neurosci. Lett. 2001, 313, 96-98. [CrossRef]

18. Nematollahi, A.; Aminimoghadamfarouj, N.; Church, W.B. Essential structural features of novel antischizophrenic drugs: A review. Med. Chem. 2014, 10, 541-549. [CrossRef] [PubMed]

19. Nematollahi, A.; Church, W.B.; Nadvi, N.A.; Gorrell, M.D.; Sun, G. Homology modeling of human kynurenine aminotransferase III and observations on inhibitor binding using molecular docking. Cent. Nerv. Syst. Agents Med. Chem. 2014, 14, 2-9. [CrossRef] [PubMed]

20. Jayawickrama, G.S.; Sadig, R.R.; Sun, G.; Nematollahi, A.; Nadvi, N.A.; Hanrahan, J.R.; Gorrell, M.D.; Church, W.B. Kynurenine aminotransferases and the prospects of inhibitors for the treatment of schizophrenia. Curr. Med. Chem. 2015, 22, 2902-2918. [CrossRef] [PubMed]

21. Han, Q.; Cai, T.; Tagle, D.A.; Li, J. Structure, expression, and function of kynurenine aminotransferases in human and rodent brains. Cell. Mol. Life Sci. 2010, 67, 353-68. [CrossRef] [PubMed]

22. Guidetti, P.; Hoffman, G.E.; Melendez-Ferro, M.; Albuquerque, E.X.; Schwarcz, R. Astrocytic localization of kynurenine aminotransferase II in the rat brain visualized by immunocytochemistry. Glia 2007, 55, 78-92. [CrossRef] [PubMed]

23. Yu, P.; di Prospero, N.A.; Sapko, M.T.; Cai, T.; Chen, A.; Melendez-Ferro, M.; Du, F.; Whetsell, W.O., Jr.; Guidetti, P.; Schwarcz, R.; et al. Biochemical and phenotypic abnormalities in kynurenine aminotransferase II-deficient mice. Mol. Cell. Biol. 2004, 24, 6919-6930. [CrossRef] [PubMed]

24. Okuno, E.; Nakamura, M.; Schwarcz, R. Two kynurenine aminotransferases in human brain. Brain Res. 1991, 542, 307-312. [CrossRef]

25. Reyes Ocampo, J.; Lugo Huitron, R.; Gonzalez-Esquivel, D.; Ugalde-Muniz, P.; Jimenez-Anguiano, A.; Pineda, B.; Pedraza-Chaverri, J.; Rios, C.; Perez de la Cruz, V. Kynurenines with neuroactive and redox properties: Relevance to aging and brain diseases. Oxid. Med. Cell. Longev. 2014, 2014, 646909. [CrossRef] [PubMed]

26. Cooper, A.J.; Shurubor, Y.I.; Dorai, T.; Pinto, J.T.; Isakova, E.P.; Deryabina, Y.I.; Denton, T.T.; Krasnikov, B.F. Omega-Amidase: An underappreciated, but important enzyme in L-glutamine and L-asparagine metabolism; relevance to sulfur and nitrogen metabolism, tumor biology and hyperammonemic diseases. Amino Acids 2016, 48, 1-20. [CrossRef] [PubMed]

27. Stone, T.W. Endogenous neurotoxins from tryptophan. Toxicon 2001, 39, 61-73. [CrossRef] 
28. Jensen, R.A.; Gu, W. Evolutionary recruitment of biochemically specialized subdivisions of family I within the protein superfamily of aminotransferases. J. Bacteriol. 1996, 178, 2161-2171. [PubMed]

29. Okamoto, A.; Kato, R.; Masui, R.; Yamagishi, A.; Oshima, T.; Kuramitsu, S. An aspartate aminotransferase from an extremely thermophilic bacterium, Thermus thermophilus HB8. J. Biochem. 1996, 119, 135-144. [CrossRef] [PubMed]

30. Guidetti, P.; Okuno, E.; Schwarcz, R. Characterization of rat brain kynurenine aminotransferases I and II. J. Neurosci. Res. 1997, 50, 457-465. [CrossRef]

31. Goh, D.L.M.; Patel, A.; Thomas, G.H.; Salomons, G.S.; Schor, D.S.M.; Jakobs, C.; Geraghty, M.T. Characterization of the human gene encoding $\alpha$-aminoadipate aminotransferase (AADAT). Mol. Genet. Metab. 2002, 76, 172-180. [CrossRef]

32. Sun, G.; Nematollahi, A.; Nadvi, N.A.; Kwan, A.H.; Jeffries, C.M.; Church, W. Expression, purification and crystallization of human Kynurenine Aminotransferase 2 exploiting a highly optimized codon set. Protein Expr. Purif. 2016, 121, 41-45. [CrossRef] [PubMed]

33. Chen, V.B.; Arendall, W.B.; Headd, J.J.; Keedy, D.A.; Immormino, R.M.; Kapral, G.J.; Murray, L.W.; Richardson, J.S.; Richardson, D.C. MolProbity: All-atom structure validation for macromolecular crystallography. Acta Crystallogr. D 2010, 66, 12-21. [CrossRef] [PubMed]

34. Denesyuk, A.I.; Denessiouk, K.A.; Korpela, T.; Johnson, M.S. Functional attributes of the phosphate group binding cup of pyridoxal phosphate-dependent enzymes. J. Mol. Biol. 2002, 316, 155-172. [CrossRef] [PubMed]

35. Denesyuk, A.I.; Denessiouk, K.A.; Korpela, T.; Johnson, M.S. Phosphate group binding "cup" of PLP-dependent and non-PLP-dependent enzymes: Leitmotif and variations. Biochim. Biophys. Acta 2003, 1647, 234-238. [CrossRef]

36. Mehta, P.K.; Hale, T.I.; Christen, P. Aminotransferases-Demonstration of homology and division into evolutionary subgroups. Eur. J. Biochem. 1993, 214, 549-561. [CrossRef] [PubMed]

37. Schneider, G.; Kack, H.; Lindqvist, Y. The manifold of vitamin B6 dependent enzymes. Structure 2000, 8, R1-R6. [CrossRef]

38. Jansonius, J.N. Structure, evolution and action of vitamin B6-dependent enzymes. Curr. Opin. Struct. Biol. 1998, 8, 759-769. [CrossRef]

39. Ku, S.Y.; Yip, P.; Howell, P.L. Structure of Escherichia coli tryptophanase. Acta Crystallogr. D Biol. Crystallogr. 2006, 62, 814-823. [CrossRef] [PubMed]

40. Hasse, D.; Andersson, E.; Carlsson, G.; Masloboy, A.; Hagemann, M.; Bauwe, H.; Andersson, I. Structure of the homodimeric glycine decarboxylase P-protein from Synechocystis sp. PCC 6803 suggests a mechanism for redox regulation. J. Biol. Chem. 2013, 288, 35333-35345. [CrossRef] [PubMed]

41. Gurusaran, M.; Shankar, M.; Nagarajan, R.; Helliwell, J.R.; Sekar, K. Do we see what we should see? Describing non-covalent interactions in protein structures including precision. IUCrJ 2014, 1(Pt 1), 74-81. [CrossRef] [PubMed]

42. Kumar, K.S.D.; Gurusaran, M.; Satheesh, S.N.; Radha, P.; Pavithra, S.; Tharshan, K.P.S.T.; Helliwell, J.R.; Sekar, K. Online_DPI: A web server to calculate the diffraction precision index for a protein structure. J. Appl. Crystallogr. 2015, 48, 939-942. [CrossRef]

43. McPhillips, T.M.; McPhillips, S.E.; Chiu, H.J.; Cohen, A.E.; Deacon, A.M.; Ellis, P.J.; Garman, E.; Gonzalez, A.; Sauter, N.K.; Phizackerley, R.P.; et al. Blu-ice and the distributed control system: Software for data acquisition and instrument control at macromolecular crystallography beamlines. J. Synchrotron Radiat. 2002, 9, 401-406. [CrossRef] [PubMed]

44. Kabsch, W. Integration, scaling, space-group assignment and post-refinement. Acta Crystallogr. D 2010, 66, 133-144. [CrossRef] [PubMed]

45. Evans, P.R.; Murshudov, G.N. How good are my data and what is the resolution? Acta Crystallogr. D 2013, 69, 1204-1214. [CrossRef] [PubMed]

46. Mccoy, A.J.; Grosse-Kunstleve, R.W.; Adams, P.D.; Winn, M.D.; Storoni, L.C.; Read, R.J. Phaser crystallographic software. J. Appl. Crystallogr. 2007, 40, 658-674. [CrossRef] [PubMed]

47. Bunkoczi, G.; Read, R.J. Improvement of molecular-replacement models with sculptor. Acta Crystallogr. D 2011, 67, 303-312. [CrossRef] [PubMed] 
48. Adams, P.D.; Afonine, P.V.; Bunkoczi, G.; Chen, V.B.; Davis, I.W.; Echols, N.; Headd, J.J.; Hung, L.W.; Kapral, G.J.; Grosse-Kunstleve, R.W.; et al. PHENIX: A comprehensive Python-based system for macromolecular structure solution. Acta Crystallogr. D 2010, 66, 213-221. [CrossRef] [PubMed]

49. Rossi, F.; Garavaglia, S.; Montalbano, V.; Walsh, M.A.; Rizzi, M. Crystal structure of human kynurenine aminotransferase II, a drug target for the treatment of schizophrenia. J. Biol. Chem. 2008, 283, 3559-3566. [CrossRef] [PubMed]

50. Han, Q.; Cai, T.; Tagle, D.A.; Robinson, H.; Li, J.Y. Substrate specificity and structure of human aminoadipate aminotransferase/kynurenine aminotransferase II. Biosci. Rep. 2008, 28, 205-215. [CrossRef] [PubMed]

51. Rossi, F.; Valentina, C.; Garavaglia, S.; Sathyasaikumar, K.V.; Schwarcz, R.; Kojima, S.; Okuwaki, K.; Ono, S.; Kajii, Y.; Rizzi, M. Crystal structure-based selective targeting of the pyridoxal $5^{\prime}$-phosphate dependent enzyme kynurenine aminotransferase ii for cognitive enhancement. J. Med. Chem. 2010, 53, 5684-5689. [CrossRef] [PubMed]

52. Tuttle, J.B.; Anderson, M.; Bechle, B.M.; Campbell, B.M.; Chang, C.; Dounay, A.B.; Evrard, E.; Fonseca, K.R.; Gan, X.M.; Ghosh, S.; et al. Structure-based design of irreversible human KAT II inhibitors: Discovery of new potency-enhancing interactions. ACS Med. Chem. Lett. 2013, 4, 37-40. [CrossRef] [PubMed]

53. Dounay, A.B.; Anderson, M.; Bechle, B.M.; Evrard, E.; Gan, X.M.; Kim, J.Y.; McAllister, L.A.; Pandit, J.; Rong, S.B.; Salafia, M.A.; et al. PF-04859989 as a template for structure-based drug design: Identification of new pyrazole series of irreversible KAT II inhibitors with improved lipophilic efficiency. Bioorg. Med. Chem. Lett. 2013, 23, 1961-1966. [CrossRef] [PubMed]

54. Krieger, E.; Joo, K.; Lee, J.; Lee, J.; Raman, S.; Thompson, J.; Tyka, M.; Baker, D.; Karplus, K. Improving physical realism, stereochemistry, and side-chain accuracy in homology modeling: Four approaches that performed well in CASP8. Proteins 2009, 77, 114-122. [CrossRef] [PubMed]

55. Afonine, P.V.; Grosse-Kunstleve, R.W.; Echols, N.; Headd, J.J.; Moriarty, N.W.; Mustyakimov, M.; Terwilliger, T.C.; Urzhumtsev, A.; Zwart, P.H.; Adams, P.D. Towards automated crystallographic structure refinement with phenix.refine. Acta Crystallogr. D 2012, 68, 352-367. [CrossRef] [PubMed]

56. Chen, V.B.; Davis, I.W.; Richardson, D.C. KiNG (Kinemage, Next Generation): A versatile interactive molecular and scientific visualization program. Protein Sci. 2009, 18, 2403-2409. [CrossRef] [PubMed]

57. Lovell, S.C.; Word, J.M.; Richardson, J.S.; Richardson, D.C. The penultimate rotamer library. Proteins 2000, 40, 389-408. [CrossRef]

58. Davis, I.W.; Arendall, W.B.; Richardson, D.C.; Richardson, J.S. The backrub motion: How protein backbone shrugs when a sidechain dances. Structure 2006, 14, 265-274. [CrossRef] [PubMed]

59. Urzhumtseva, L.; Afonine, P.V.; Adams, P.D.; Urzhumtsev, A. Crystallographic model quality at a glance. Acta Crystallogr. D 2009, 65, 297-300. [CrossRef] [PubMed]

60. DeLano, W.L. The PyMOL Molecular Graphics System; DeLano Scientific LLC: San Carlos, CA, USA, 2002.

61. Gasteiger, E.; Gattiker, A.; Hoogland, C.; Ivanyi, I.; Appel, R.D.; Bairoch, A. ExPASy: The proteomics server for in-depth protein knowledge and analysis. Nucleic Acids Res. 2003, 31, 3784-3788. [CrossRef] [PubMed]

62. King, R.D.; Sternberg, M.J.E. Identification and application of the concepts important for accurate and reliable protein secondary structure prediction. Protein Sci. 1996, 5, 2298-2310. [CrossRef] [PubMed]

(C) 2016 by the authors; licensee MDPI, Basel, Switzerland. This article is an open access article distributed under the terms and conditions of the Creative Commons by Attribution (CC-BY) license (http://creativecommons.org/licenses/by/4.0/). 